\title{
In vitro fertilization of the rock shrimp, Rhynchocinetes typus (Decapoda, Caridea): a review
}

\author{
Enrique M Dupré and Claudio Barros \\ Depto. Biología Marina, Facultad de Ciencias del Mar, Universidad Católica del Norte, Coquimbo, Chile. E-mail: edupre@ucn.cl
}

\begin{abstract}
This review compiles all the research done on gametes and fertilization in the rock shrimp, $R$. typus, and describes the sequence of events from the first gamete interaction to zygote formation and the first cleavage of the embryo, with light, fluorescence confocal and electron microscopes. Early studies showed that sperm from the vas deferens have a tack-shape with a "needle-like process" or rigid spike (RS) that extends from a semi-spherical body that contains the arms with chromatin and spines. Upon contact with seawater and by action of $\mathrm{Na}+$, the arms and spines extend, producing an inverted umbrella form of the spermatozoa. The first sperm-oocyte interaction occurs between protein receptors type lectins of the sperm RS and oocyte chorion sperm ligands. These ligands contain residues of $\alpha$-Glu, Man ( $\alpha$ 1-3) Man, $\alpha$ and $\beta$-GlcNAc and $\alpha$-GalNA terminal residues. It was found that $\alpha$-Man and GlcNAc residues are the ligands that are directly related to the adhesion process and further penetration of sperm. After this first interaction, the RS enters the oocyte envelope by the action of a trypsin-like enzyme, rhynchocinecine, present in the acicular process. Later, arms and spines penetrate the oocyte cytoplasm, where the chromatin of the arms begin to migrate to the central area of the sperm, condensing in a cup-shaped structure near the connecting piece, which forms the male pronucleus.
\end{abstract}

Key words: Spermatic ultrastructure, oocyte, sperm-egg interaction, lectins.

\section{INTRODUCTION}

The rock shrimp, Rhynchocinetes typus is a marine species native to the long coast of South America. This shrimp is a commercial species and an excellent animal for aquaculture because, in addition to being highly palatable, it does not burrow, has a large feeding range and is resistant to manipulation. Its potential for aquaculture will be aided by a complete understanding of the reproductive biology of the species. Until now, numerous studies have been conducted about the structure and ultrastructure of gametes and sperm-egg interaction. However there are no compilations of these investigations. This study summarizes the main results obtained by the group of Dr. Claudio Barros about the reproduction of this species.

Decapod crustacean spermatozoa are atypical, nonflagellated and non-motile. Two basic models of spermatozoa can be recognized, based on their morphology (Talbot and Summer, 1978; Medina and Rodríguez, 2005). They correspond to two taxonomic groups: the pleocyemata, formerly known as reptantian, which includes lobsters, crabs and crayfish, and the dendrobranchiata, formerly known as natantians, which includes shrimps and prawns. The pleocyemata sperm has a spherical or elongated body with complex globular or elongated acrosome (Talbot and Chanmanon, 1980; Brown, 1966; Langreth, 1965, 1969; Moses, 1961; Klaus et al., 2009; Simeó et al., 2010), a structure-organelle complex (Simeó et al., 2010; Anderson and Ellis, 1967), a nucleus with uncondensed chromatin (Hinsch, 1971; Brown, 1966; Langreth, 1969) and 3-7 radiating arms containing microtubules (Moses, 1961; Brown, 1966; Hinsch, 1971; Talbot and Summers, 1978; Dupré and Schatten, 1994; Lohrmann and Raineri, 1995). The dendrobrachiatan sperm has a single appendage or spike (believed to be an acrosome) radiating from the main body. This type of sperm has different shapes in different groups of shrimps. The Penaeidea sperm is tack-shaped, as are those of Penaeus setiferous, Penaeus aztecus, (Clark et al., 1973; Brown et al., 1976) and Sicyonia ingentis (Clark et al., 1981a, 1981b; Yudin et al., 1979, 1980; Kleve et al., 1980), while the Caridea group has sperm with a main bell-shaped body containing the chromatin and a spike in the vortex of the body, as does the sperm of Paleomon elegans (Pochon-Masson, 1969); Paleomonetes paludosus (Koheler, 1979) and Macrobrachium rosembergii (Sandifer and Lynn, 1981; Lynn and Clark, 1980, 1983a, 1983b), or an inverted umbrella shape, as in the sperm of Rhynchocinetes typus (Dupré and Barros, 1983). It has been reported that $R$. typus constitutes a third type of spermatozoon, an exception to the dendrobranchiata pattern (Dupré, 1991), since this sperm presents a single spike like all the groups, but with 9-13 radial arms (Dupré and Barros, 1983) with actin filaments and tubuline-like proteins (Perez et al., 1990), which is a characteristic of the pleocyemata group.

Despite numerous studies about dendrobranchiatan sperm ultrastructure (Pochon-Masson, 1969; Clark et al., 1973, 1981a, 1981b; Koheler, 1979; Yudin et al., 1979; Kleve et al., 1980; Lynn and Clark, 1983a; Dupré and Barros, 1983: Klaus et al., 2009), the different functions of the spermatic structure are generally unknown. The destination of sperm components after penetration into the oocyte and male pronuclear organization have not been established either.

The present study is a review of the numerous investigations about gametes and sperm-egg interaction (Barros et al., 1986; Bustamente et al., 2001; Dupré et al., 2010) of the rock shrimp R. typus, including structure (Dupré and Bellolio, 1994; Dupré and Schaaf, 1996; Cabrera, 2003; Pinto, 2003), ultrastructure of the gametes (Pérez et al., 1990; Pérez 
et al., 1991; Dupré and Barros, 1993; Palomino et al., 2002), the first interaction (Gómez, 2002; Gómez and Dupré, 2002; Araya, 2005; Dupré et al., 2010) and fertilization (Dupré, 1991; Hierro, 1994; Ríos, 1997; Palomino, 2000). The results of these studies have elucidated the sequence of events during fertilization and can be extrapolated to other Caridea species.

\section{METHODS}

\section{Animals}

Mature female and male Rhynchocinetes typus (Crustacea Decapoda) were captured by traps in La Herradura Bay, Coquimbo, Chile $\left(71^{\circ} 50^{\prime} \mathrm{W}, 33^{\circ} 01^{\prime} \mathrm{S}\right)$ and placed in 2,000-liter tanks with filtered natural seawater in open circulation at 13 to $15^{\circ} \mathrm{C}$ with continuous aeration and 15 hours of light for periods of up to three months. The animals were fed ad libitum with boiled shrimps and clams.

\section{In vitro fertilization}

Spermatozoa were obtained from adult males $(18-20 \mathrm{~cm}$ or larger) by dissecting the vas deferens or by electrically stimulating the gonopore placing a pair of electrodes, connected to a $1.5 \mathrm{~V}$ battery at the base of the fifth pair of pereiopods. The ejaculate was collected with a Pasteur pipette and placed in a Petri dish containing $2 \mathrm{~mL}$ of filtered seawater ( $0.2 \mathrm{~mm}$ pore size) and the spermatozoa allowed to disperse in the seawater for about 30 minutes. At the end of this period, mature eggs were added to the sperm suspension and allowed to interact in vitro for 5-10 $\mathrm{min}$ at room temperature.

Oocytes were obtained from mature females maintained in 20-liter seawater tanks and 48 hours after molting, the ovaries were dissected and transferred to the sperm suspension. The oocytes were characterized by a brown-yellow color, 550$\mu \mathrm{m}$ diameters or larger and easily disaggregated when the dissected ovary was shaken in the water.

The oocytes were washed twice in filtered seawater, transferred to Falcon dishes with $2 \times 10^{5}$ spermatozoa $/ \mathrm{ml}$. In vitro fertilization was achieved by gently shaking the dish intermittently ( $3-10 \mathrm{~min})$. After insemination, the oocytes were washed 4 times and fixed as described below for their study with the transmission and scanning electron microscopes.

To compare in vitro and natural fertilized oocytes, mature female were mated 24 hours after molt and 36 hours later fertilized oocytes were obtained and fixed in $2 \%$ glutaraldehyde as described below.

Identification of carbohydrates on oocyte envelopes

Batches of 40-50 intact oocytes or isolated enveloped oocytes were pre-treated at $21^{\circ} \mathrm{C}$ for $30 \mathrm{~min}$ in $1 \mathrm{~mL}$ phosphate buffer saline (PBS) containing bovine seroalbumin $3 \mathrm{mg} / \mathrm{mL}$ (BSA) and incubated at $25^{\circ} \mathrm{C}$ for $30 \mathrm{~min}$ in $100 \mathrm{~mL}$ of solutions of seven different lectins, each dissolved in PBS + BSA $3 \mathrm{mg} /$ $\mathrm{mL}$ conjugated with fluorescein isothiocyanate (FITC). The lectins used were: (1) Concanavalin-A (Con-A) to recognize glucose (Glc), (2) Glanthus nivalis (GNL) for mannose ( $\alpha$ 1-3) mannose (Man-Man), (3) Lens culinaris agglutinin (LCA) for $\alpha$-mannose (Man) and $\alpha$-glucose (Glc), (4) Lotus tetranoglobus agglutinin (LTA) for fucose (Fuc), (5) Badeiraea simplicifolia-I
(BS-I) for galactose (Gal), (6) Griffonia simplicifolia (GSL II) for N-acetylglucosamine (N-AcGlc), and (7) Dolichos biflorus agglutinin (DBA) for $\mathrm{N}$-acetylgalactosamine (N-AcGal) at concentrations of $10 \mathrm{mg} / \mathrm{mL}$ each. They were incubated in the dark at $18^{\circ} \mathrm{C}$ for $20 \mathrm{~min}$, washed three times in PBS, and mounted and examined using a Nikon Fluophot fluorescence microscope. Samples were photographed using a Nikon FX35 camera. Control oocytes were prepared using the same procedure with the exception of incubation of oocytes in FITClabeled reagents, for which a parallel incubation in PBS was substituted. To standardize the fluorescence, a positive sugar control was used; samples contained $250 \mathrm{mM}$ solution of the appropriate blocking sugar (Man, Glc, Fuc, Gal, N-AcGlc, $\mathrm{N}$-AcGal) pre-incubated with the lectin for $10 \mathrm{~min}$ prior to application to envelopes.

Isolated oocyte envelopes were rinsed with three changes of PBS and mounted on microscope slides with $1 \%$ polylysine. They were then rinsed with PBS and separate samples were incubated in each of the lectins listed above using the same protocol as that used for the oocytes. Controls were prepared using the same methods but substituting the incubation in lectins by PBS. Measurements of fluorescence intensity on both intact and isolated oocyte envelopes were carried out using a Nikon HFX-II automatic photometer attached to the microscope, with a 40X objective.

To determine if any of these monosaccharides tested participate in fertilization, an in vitro assays of fertilization inhibition was realized. The inhibition of fertilization test was achieved by incubation of spermatozoa previously treated with $\alpha$-glucose $(\alpha-G l c)$, galactose (Gal) and fucose (Fuc), $\mathrm{N}$-acetylglucosamine ( $\alpha$-Glc-NAc) and $\mathrm{N}$-acetylgalactosoamine $(\beta-$ Gal-NAc) and then incubated with mature oocytes (Dupré et al., 2010). The monosaccharides blocked the active site of a lectin-like protein on the rigid spike of the spermatozoa that binds to the oligosaccharides ligands on the surface of the egg coat. After 4 hours, the fertilization percentages were determined.

\section{Electron microscope studies}

At the desired times after insemination, fertilized eggs were fixed for 2 hours with $2 \%$ glutaraldehyde, prepared in normal filtered seawater (FSW), $\mathrm{pH}$ adjusted to 7.4 at room temperature $\left(15-17^{\circ} \mathrm{C}\right)$. Then they were divided into two groups: the first group was prepared to be analyzed with the scanning electron microscope and the other group was prepared for transmission electron microscopy.

For scanning electron microscopy, spermatozoa, oocytes and fertilized oocytes, after fixing the fertilized eggs, were washed three times in FSW and dehydrated in a series of acetones of increasing concentration. The eggs were critical point-dried in a Samdri or Sorvall apparatus, and then sputtered with a gold-palladium electrode in a Pelco ${ }^{\circledR} 91,000$ sputter. Observations were made on a Leo $1420 \mathrm{VP}$ or Jeol JSM-T300.

For the transmission electron microscopy, after fixation the samples were rinsed in several changes of filtered seawater, $\mathrm{pH} 7.4$ and then post-fixed in $1 \%$ osmium tetroxide prepared in FSW, pH 7.4 (Dupré and Barros, 1983; Ríos and Barros, 1997), rinsed in FSW and then dehydrated for 5-15 $\min$ in a graded ethanol series. Then they were infiltrated in a 3:1, 1:1, 1:3 ethanol-LR White mixture and finally in pure LR White. 
Polymerization was obtained at $4^{\circ} \mathrm{C}$ under UV light for periods of 12-24 hours. Other samples were embedded in a low viscosity epoxy resin Spurr and polymerized at $50^{\circ} \mathrm{C}$. Gold and gray sections were stained with uranyl acetate and lead citrate standard conditions and then examined in a Phillips Tecnai-12 or in a Siemens 102 electron microscope.

\section{Light and confocal microscopy}

For light and confocal microscopy, after fixation oocytes were cleared in methanol-chloroform (1:1) for 1-2 days, then transferred to $2 \%$ lacto-acetic orcein for $3 \mathrm{~min}$ and rinsed with $50 \%$ acetic acid to eliminate the excessive dye. For light microscopy, the oocytes were analyzed by Nomarski illumination in a Zeiss Universal microscope. Other fertilized oocytes were incubated after fixation with $4 \mu \mathrm{M}$ thiazole orange in DMSO for $5 \mathrm{~min}$, rinsed in PBS for $1 \mathrm{~min}$, mounted in Slow Fade (Molecular Probes Inc.) and analyzed in BioRad MCR-600 laser scanning confocal microscope (Dupré and Schatten, 1994).

For the description of spermatozoa structures, the terminology of Dupré and Barros (1983) was used.

\section{RESULTS}

Vas deferens spermatozoa are thumbtack-shaped (Fig. 1a). Immediately upon placement in seawater they unfold radial arms and spines (Fig. 1b). In any given individual shrimp one can find spermatozoa with 9, 10, 11, 12 and 13 arms and radial spines. All arms are coplanar and converge to a center from which a rigid spike emerges about $53 \mu \mathrm{m}$ long (Fig. 1c, d) (Dupré and Barros, 1983; Dupré, 1991). As has been observed in the mature spermatozoa treated with the fluorochrome Hoechst 33258, the uncondensed chromatin is contained in each arm (Fig. 1e, 1f, 1g). The arms and spike are bound by a homogeneous and high electron density stellatte structure termed the "connection piece" (Fig. 1b). In mature spermatozoon, a centriole is associated with this structure (Dupré and Barros, 1983).

The opening or unfolding of the spermatozoa is caused by a mechanism triggered by the sodium ion in the seawater (Dupré and Schaaf, 1996). In addition to $\mathrm{Na}^{+}$, cations, such as $\mathrm{K}^{+}, \mathrm{Li}^{+}, \mathrm{NH}^{+}, \mathrm{K}^{+}$and $\mathrm{Na}^{+}$at high concentrations, can induce the opening of spermatozoa. It is suggested that these ions are associated with an intracellular shift in $\mathrm{pH}$ that induces the polymerization of cytoskeletal components, found in the arms and spines (Dupré and Bellolio, 1994) as microfilaments and tubuline-like protein (Pérez et al., 1991). One mechanism that has been suggested is that initially there is an interchange of an $\mathrm{Na}^{+}$and $\mathrm{H}^{+}$ion through the plasma membrane; the output of $\mathrm{H}^{+}$produces an increase in intracellular $\mathrm{pH}$ that allows the rapid assembly of microtubules and/or actin, when the control-associated protein dissociates from the nonfilamentous state of those proteins and induces polymerization into bundles of filaments in the arms, thus generating their extension and starting the unfolding process (Dupré and Schaaf, 1996).

Oocytes fixed directly from the ovary have a total diameter of $549 \mu \mathrm{m}$ and are covered by a $10-\mu \mathrm{m}$-thick transparent envelope. Electron microscope sections (dehydrated) of the egg envelope (Fig. 2) revealed an electron-dense external coat of $0.4 \mu \mathrm{m}$ covered by filamentous processes, and a granular inner coat of $4-\mu \mathrm{m}$ thickness. Oocytes placed for $5 \mathrm{~min}$ in seawater had a significantly larger diameter $(573 \mu \mathrm{m})$, because of the increase in the thickness of the egg coats $(32 \mu \mathrm{m})$ and the formation of a $16-\mu \mathrm{m}$ perivitelline space (Fig. $3 \mathrm{~b}$ ). The diameter of the egg proper was reduced by the same extent as the size of the perivitelline space. All these changes were associated with the loss of the egg fertilizability (Palomino et al., 2002).

\section{First sperm-egg interaction}

Sperm-egg association is established between the tip of the rigid spike and the outermost chorion of the egg (Barros et al., 1986) (Fig. 3a, 3b, 3c). This binding seems to be strong because it is not disrupted by pippeting (Barros et al., 1986)
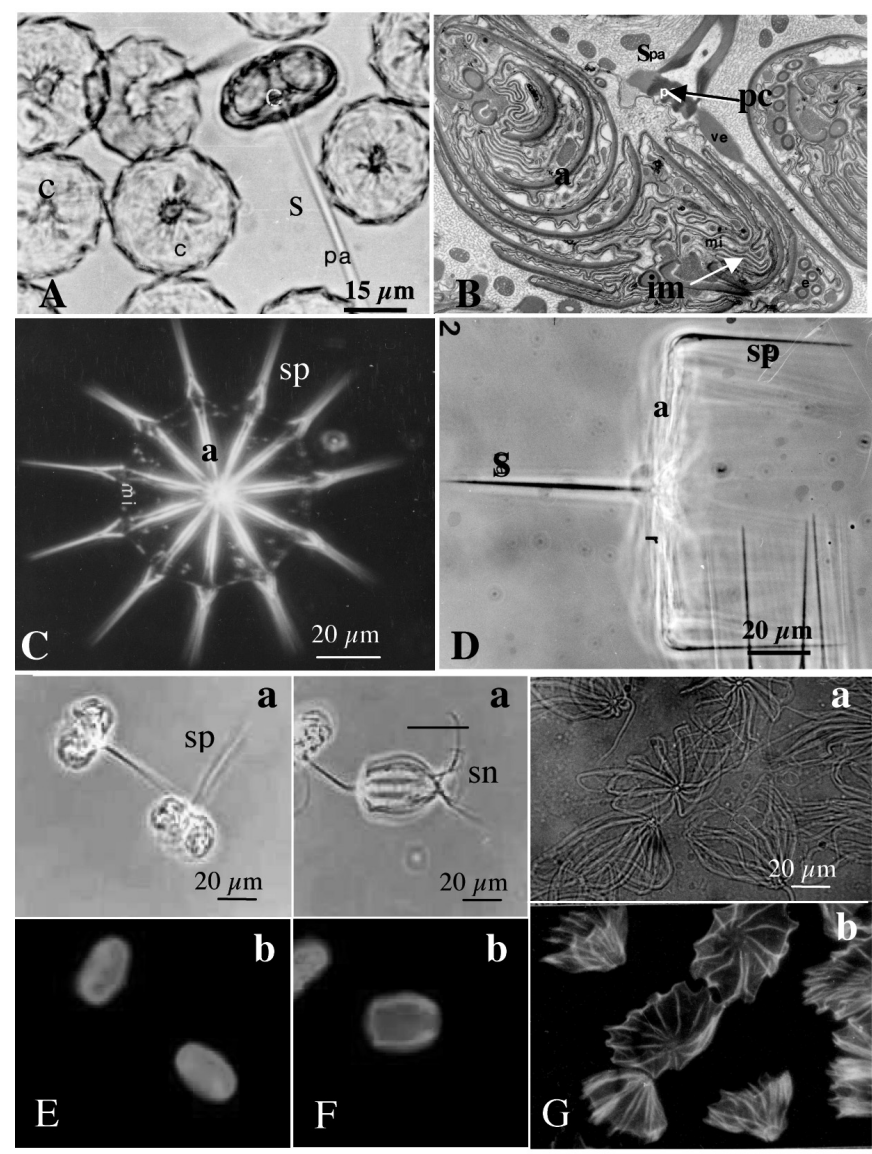

Figure 1: Structure and ultrastructure of spermatozoa. A, light microscopy view of vas deferens spermatozoa. B. Transmission electron micrograph of a sagital section through vas deferens spermatozoa showing the arms (a) longitudinally cut, interarms sheet (im) and tangential section of the spike (s) and the connection piece (cp) as higher electron density at the base of the spike. $C$, polar view and $D$, lateral view of unfolded spermatozoa show the spike (s), arms (a) and spines (sp). E, F, G, spermatozoa stained with Hoechst 33258 and observed with bright field (a) and fluorescence microscope (b). Note that fluorescence is restricted to the arms folded in the body being the spike (sp) and radial spines (sn) non fluorescent. $E$, vas deferens spermatozoa. $F$, sea water spermatozoa with the arms partially unfolded. G, sea water spermatozoa unfolded spermatozoa from sea water. Note de fluorescence in the arms. (E, F, from Pinto, 2003; G, from Dupré and Barros, 1983). 
and after the whole treatment for their study with the scanning electron microscope, where high vacuum is normally used. This suggests that during sperm-egg interaction in this species, a binding-like molecule might be involved. Studies we conducted in 2001-2002 showed this strong binding. We determined the presence and location during oocyte maturation of the monosaccharids mannose $\alpha$-mannose ( $\alpha$-Man), $\alpha$ - glucose ( $\alpha$-Glc), galactose (Gal) and fucose (Fuc) on the egg coating using the following specific FITC-labeled lectins: LCA, Con-A, BS-1 and LTA respectively (Gómez, 2002; Gómez and Dupré, 2002) (Fig. 4). Later Araya (2005), using the same four specific lectins and 3 other specific lectins: GNL, GLS-II and DBA for the recognition of mannose- $\alpha$ 1-3- mannose (man-1-3-man), N-acetylglucosamine ( $\alpha$-Glc$\mathrm{NAc}$ ) and $\mathrm{N}$-acetylgalactosoamine ( $\beta$-Gal-NAc) respectively, determined that $\alpha$-Man, man-1-3-man and $\alpha$-Glc-NAc had the highest percentages of all the monosaccharides tested, $\alpha$-Man being three times as high as $\alpha$-Glc-NAc and two times as high as man-1-3-man (Fig. 4).
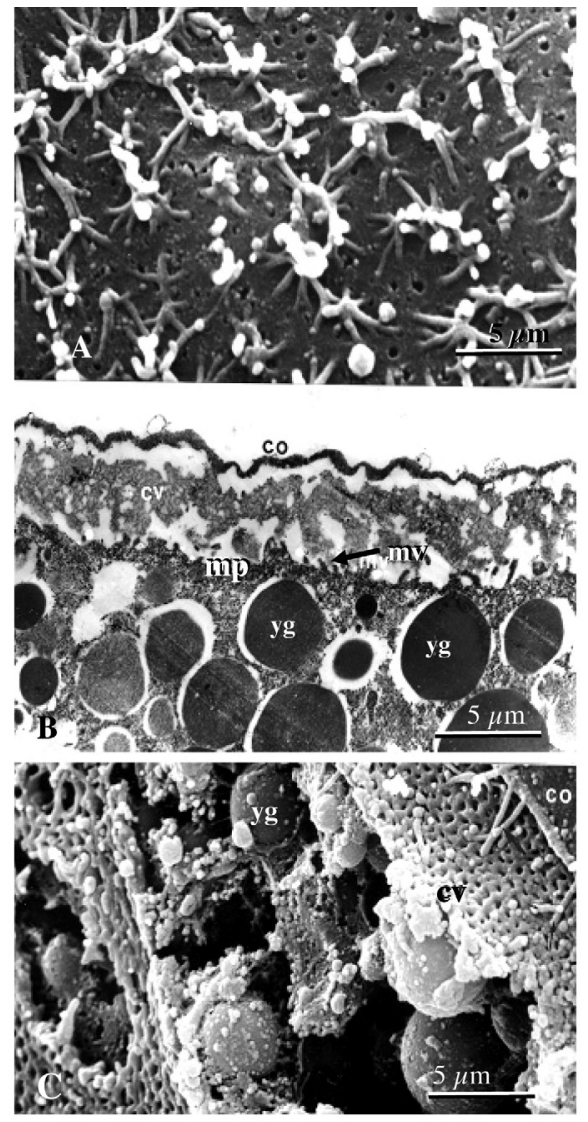

Figure 2: Electron microscope micrograph of investment of oocyte. A, SEM view of the most external egg envelope, the chorion, with disklike formation conformed by the confluence of several filaments processes. B, MET view showing the outer most layer, the chorion (co), the fenestrated vitelline coat (cv), the plasmatic membrane ( $\mathrm{mp}$ ) with microvilli (mv) and yolk granules (yg) inside the oocyte. C, SEM view showing the chorion (co), the fenestrated vitelline coat (cv) through a small hole the microvilli of oocyte membrane crossing through the fenestrated vitelline coat. Yolk granules (yg).
Results of lectin and in vitro fertilization inhibition assays showed that $\alpha$-man, $\alpha$-Glc and $\alpha$-Glc-NAc generated the highest inhibition of fertilization (Araya, 2005). Despite the low concentration of $\alpha$-Glc-NAc in the envelope, it showed the highest degree of inhibition of fertilization (Fig. 5). These results suggest that this monosaccharide could be the main receptor for the first gamete interaction, but it has also been argued that $\alpha$-mannose and $\alpha$-glucose could be complementary receptors to $\mathrm{N}$-acetylglucosamine because of their high concentrations on the coat. It was concluded that $\alpha$-man, $\alpha$-Glc and $\alpha$-Glc-NAc ligands on the surface of oocyte coat bind a lectin-like protein to the spermatozoon spike to generate a strong binding during the first interaction of the gametes.

After the first sperm-egg interaction, the spike of the spermatozoon begins to penetrate the chorion and reach the perivitelline space (Fig. 6). Despite the absence of an acrosome-
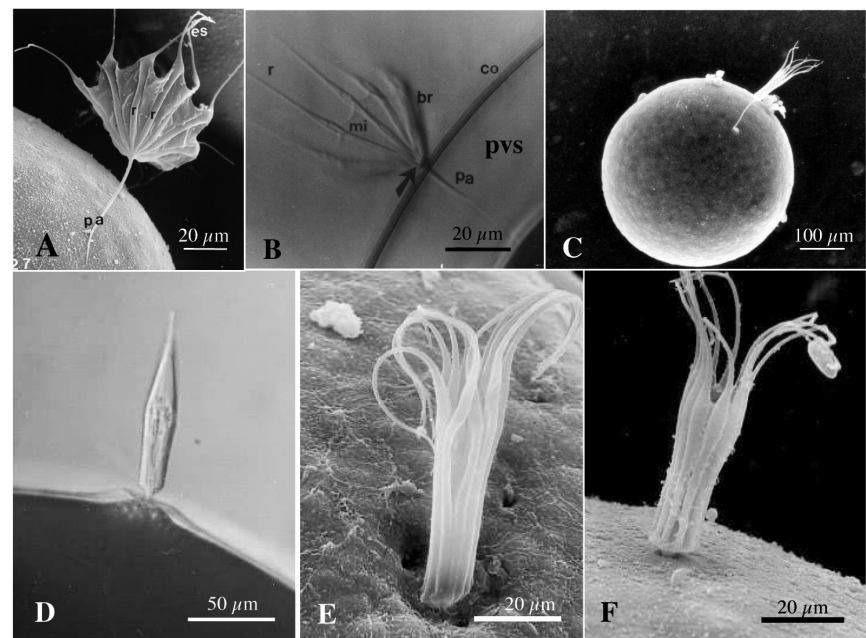

D



Figure 3: Sequence of spermatozoon penetration through eggcoat. A, first interaction between the spike (pa) and the outermost coat, the chorion. B. penetration through the egg-chorion (co). Note the elevated chorion (co), the perivitelline space (pvs) and the inverted umbrella-shape of the spermatozoon showing the arms (br) bound together by a inter-arms membrane ( $\mathrm{mi}$ ) and the radial spines ( $r$ ). $C$, distal end of the spike fuse with the chorion, notes the arms and spines of the sperm become parallels between them and in the same axis as the rigid spike. D, the arms appear completely fused among each other. Note the fertilization cone around the spike. E and F Scanning electron microscopy (SEM) view at the end of spike penetration and the arms begin to fuse to each other. G, SEM view of the arms penetration in different stages. $\mathrm{H}$, half of the arms have already penetrated and fusing with the egg-coat. I, final penetration of the sperm showing distal end of its arms and the spines. The arrow shows the connection piece position. 
like structure or any change during gamete interaction, which could be interpreted as an acrosome reaction, as has been observed in this species, the rigid spike of the spermatozoon exerts a lytic effect on the egg coat (Fig. 6e, 6f), which results in a perforation through which the sperm penetrates the egg coat (Barros et al., 1986). In subsequent work (Ríos and Barros, 1997) sperm extracts in polyacrylamide-gelatine gels showed proteasic activity that was completely inhibited by $0.1 \mathrm{mM}$ SBTI (soybean trypsin inhibitor), and $0.1 \mathrm{mM} \mathrm{pAB}$ (p-aminobenzamidine), supporting the hypothesis that a trypsin-like enzyme is involved in sperm passage through the egg coat during fertilization. Later, Bustamante et al. (2001) isolated a trypsin-like enzyme, named rhynchocinesina, from mature spermatozoa with a maximal activity at $27^{\circ} \mathrm{C}, \mathrm{pH} 8.0$

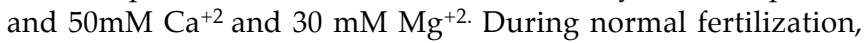
after the first contact with the egg, the sperm undergoes a drastic change in shape. The arms, which at the initial contact were open at an angle about $45^{\circ}$ to the egg surface and approximately perpendicular to the rigid spike (Fig. 3a), become aligned parallel to each other and in the same axis as the rigid spike (Fig. 3c-e, 7a-b) (Barros et al., 1986). A similar change has been described when solubilized egg coats were placed with vas deferens sperms (Palomino, 2000; Palomino et al., 2002). The egg coat components seem to have an effect on sperm egg interaction since solubilized egg coat proteins can have an inhibitory action on the rate of in vitro fertilization in a dose dependent manner (Palomino et al., 2002). After parallel alignment, the arms begin to enter the oocyte (Fig. 3g-i).

Preliminary studies regarding zygote formation have been done with the scanning electron microscope (Barros et al., 1986), and later with the transmission electron microscope in which the gamete membranes involved in the formation of the zygote have been viewed (Pinto, 2003).

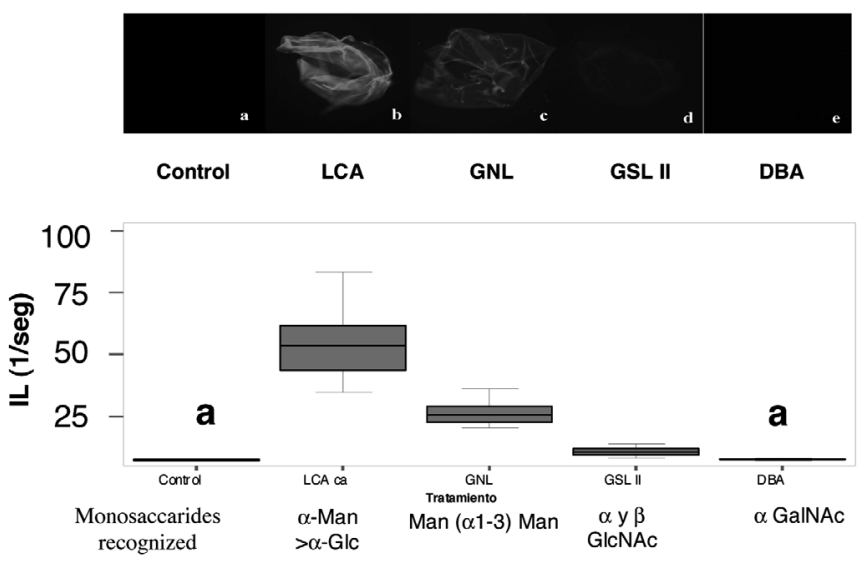

Figure 4: Egg-coat isolated and treated with different lectines showing the different fluorescence index (IL). The image shows LCA and GNL are the highest fluorescence. This fluorescence showed $\alpha$-Man and $\alpha$-glucose are the highest saccharides on the egg-coat. The lectin used were: Lens culinaris agglutinin (LCA) for $\alpha$-mannose ( $\alpha$-Man) and $\alpha$-glucose $(\alpha$-Glc), Glanthus nivalis (GNL) for mannose ( $\alpha$ 1-3) mannose (man $\alpha 1-3 m a n)$, Griffonia simplicifolia (GSL II) for $\mathrm{N}$-acetylglucosamine ( $\alpha$ - and $\beta$ GlcNAc), and Dolichos biflorus agglutinin (DBA) for $\mathrm{N}$-acetylgalactosamine $(\alpha-$ GalNAc) at concentrations of $10 \mu \mathrm{g} / \mathrm{Ml}$.
Sequence of penetration of the spermatozoa

About 10-20 min after gamete contact, a perforation in the chorion is observed (Fig. 6d-e). At this time, the longitudinal striation of the rigid spike (Fig. 6c) becomes less evident (Fig. $6 \mathrm{~d}-\mathrm{f})$. Once the incorporation of the rigid spike is complete, the arms begin to incorporate into the egg cytoplasm (Fig. 7a-c). At the end of incorporation of spermatozoon, the first meiotic spindle of the oocyte is observed (Fig. 8). Later, the extrusion of a bipolar body is observed (Fig. 9e) (Hierro, 1994).

About 35 minutes after insemination, the arms are completely incorporated and only the radial spines remained outside the egg (Fig. 3h, 3i). The whole penetration process is completed between 45 and 60 min post-insemination (Fig. 7).

After the whole spermatozoon is incorporated into the oocyte, it conserves its characteristic shape, however none of the sperm structures are surrounded by plasmatic or similar membrane when observed by TEM (Cabrera, 2003) (Figs. 7g). Eight hours post-insemination, the spike begins to disorganize itself, evidencing a fibrillar structure. Each of these fibers is 10 $\mathrm{nm}$ wide and presents cross striations with a periodicity of 34.5 nm.

When observed with confocal microscopy, at the moment the first oocyte meiotic spindle appears (Fig. 7e), sperm chromatin migrates from each ray towards the center of the spermatozoon where they concentrate near to the connection piece in a cup shaped structure (Fig. $7 \mathrm{~g}$-h). In TEM micrographs, diffused chromatin between the rays and the spermatozoon central zone was observed, together with mitochondria associated with the channel-like sheaths of the rays.

At 12 hours post-insemination, the male pronucleus is surrounded by mitochondria and endoplasmic reticulum and its membrane presents deep invaginations. At 19 hours postinsemination, the chromatin is condensed in chromosomes (Fig. 9) and the arms and striated rods of the arms begin to disintegrate in the cytoplasm (Fig. 7d).

After 36 hours post-insemination, the mitotic spindle of the first cleavage was observed (Fig. 9). No spermatic structures were observed except for a stellated or gear-shaped structure associated with the spindle that corresponds to the connection piece of spermatozoon (Fig. 1b, 9a-b).

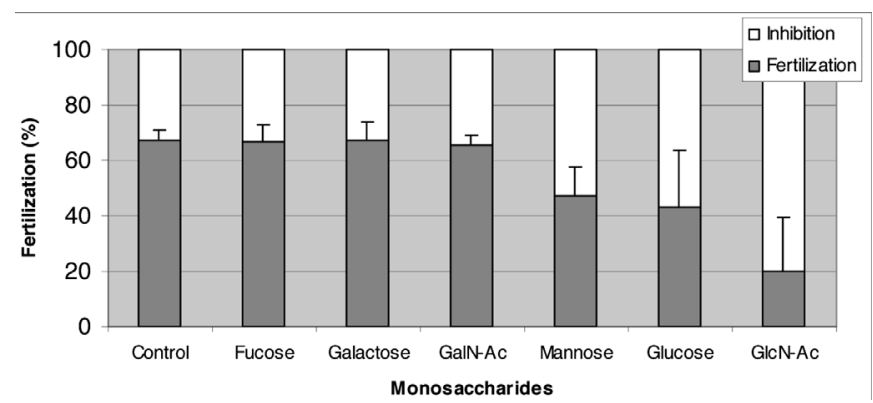

Figure 5: Percentage of fertilization (and inhibition) of oocyte inseminated with pre-treated spermatozoa with different monosaccharides (at concentrations $0.25 \mathrm{M}$ ). Despite the $\mathrm{N}$-acetylglucosamine (GlcN-Ac) shows low fluorescence on the coat, it was the highest inhibitor of the fertilization. ( $\alpha$-GalN-Ac), $\mathrm{N}$-acetylgalactosamine. 
A later study (Dupré, 1991) determined that this connection piece is the only spermatic structure present at the beginning of the first mitotic spindle of the embryo and associated with it. This could indicate that the centriole or centrosome associated with the connection piece could act as a microtubuleorganizing centre before and during the formation of the first mitotic spindle of first cleavage of the egg.

From a comparative biology point of view, all these studies make significant contributions understanding the Caridean fertilization model, which is significantly different from those of other animal species and very importance for understanding animal biodiversity.

\section{DISCUSSION}

\section{Spermatic components}

Centriole in the Decapod crustacean spermatozoa has been described in the pleocyematan, as in P. elegans (Pochon-Masson, 1969), R. typus (Dupré and Barros,1983) and $M$. rosembergii (Lyn and Clark, 1983a,b); and the dendrobranchiatan as in Cambarus sp. (Anderson and Ellis, 1967), Cancer borealis (Langreth, 1965), Libinia emarginata (Hinsch, 1969), Homarus vulgaris (Pochon-Masson, 1965),

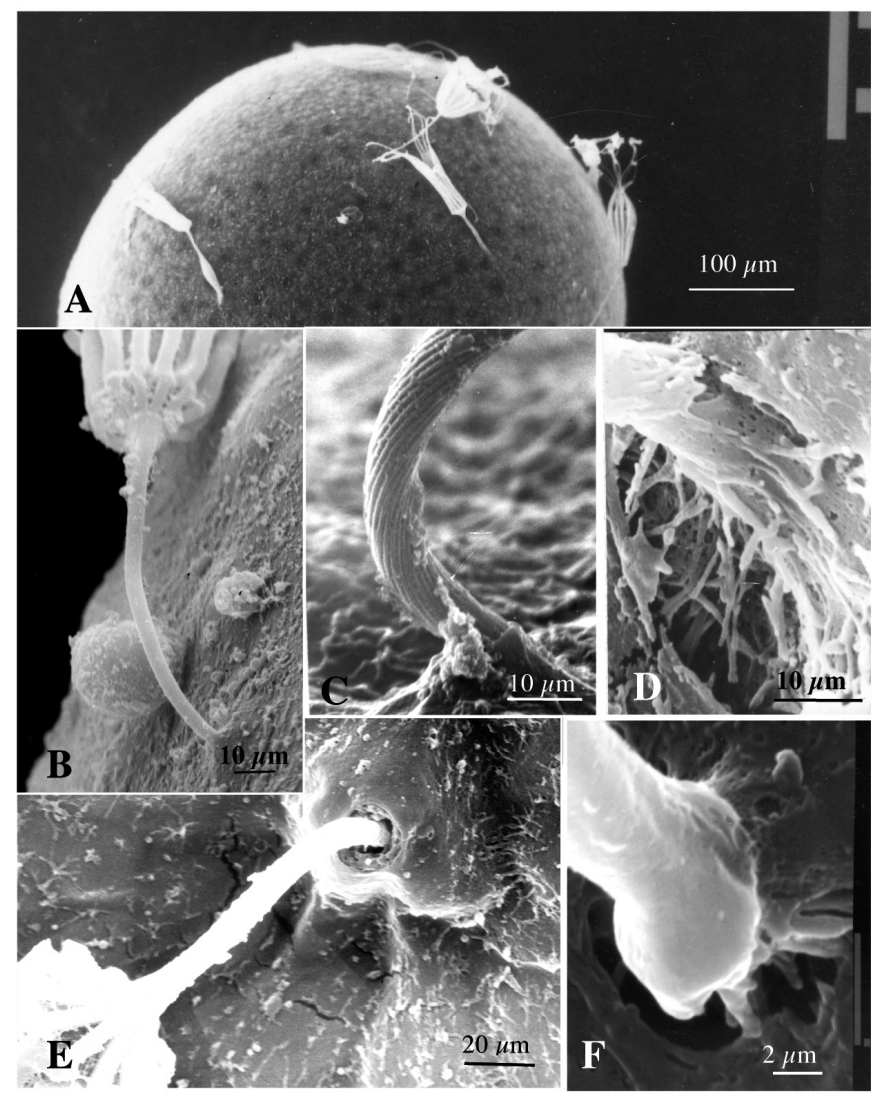

Figure 6: Scanning electron micrographs of sperm-egg interaction. A. A polyspermic oocyte; first contact between the egg surface and the tip of the spermatozoa spike as show in B and C. Note longitudinal striation of the spike. D, E, F, Lytic action on the egg surface after initial contact. The longitudinal striation of the spike is not evident at this time. ( $E$, from Rios and Barros, 1997)
Nephrops norvegicus (Chevaillier and Maillet, 1965) and Panulirus argus (Talbot and Summers, 1978).

The connection piece (CP) of the $R$. typus spermatozoon remains in the cytoplasm of the zygote, although the rest of its structure has been disaggregated. This suggests that the connection piece, which has an associated centriole (Dupré,
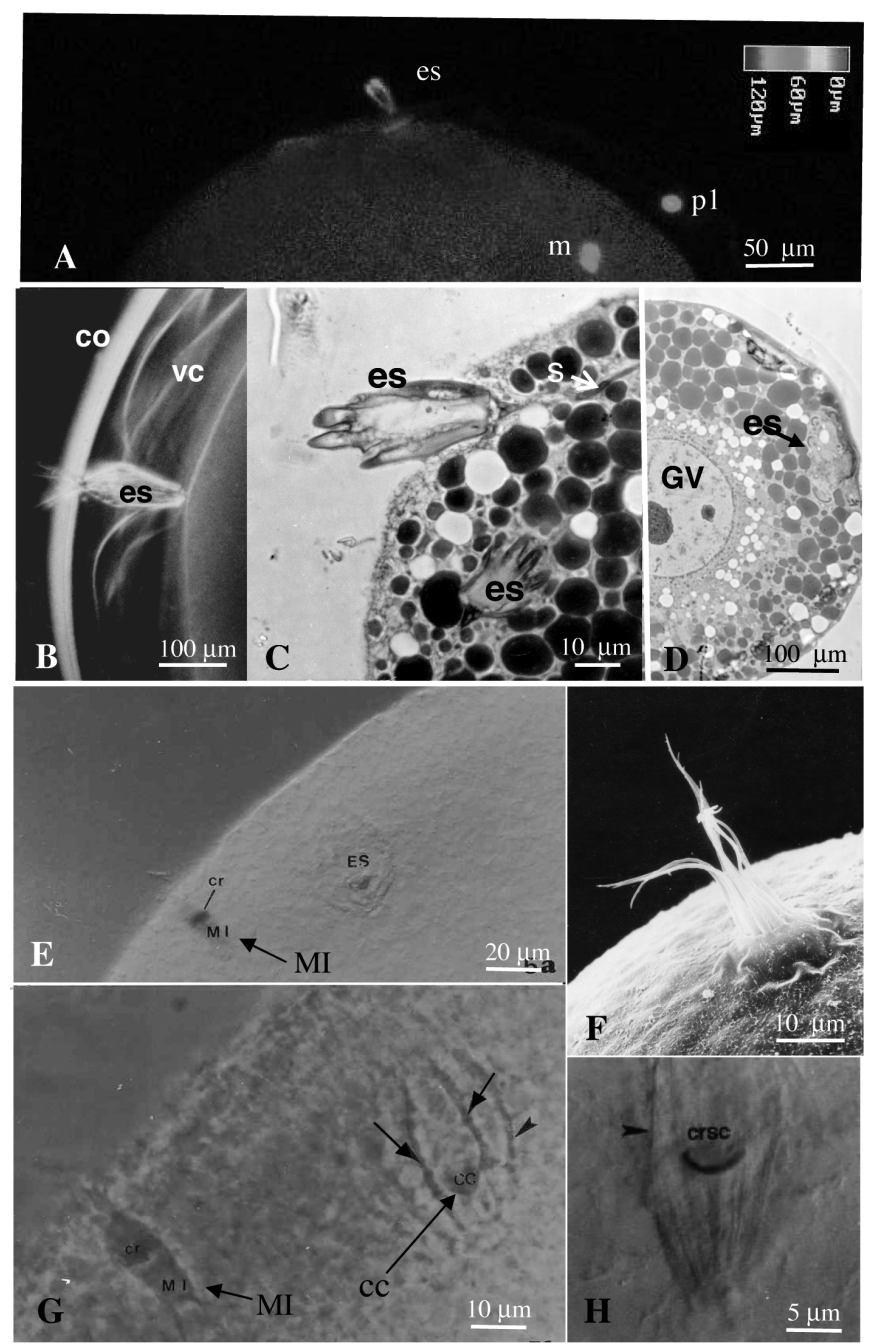

Figure 7: Spermatozoa entry into the ooplasm. Spermatozoa (es) penetration through the egg-coat observed with a confocal (A) and light microscope (B). Note the first ( $\mathrm{p} 1)$ and second meiotic telophase $(\mathrm{m})$ inside of the oocyte, the chorion ( $\mathrm{co}$ ) and vitelline coat in the perivitelline space. $C$, transmission electron micrograph of a sagital section through the sperm in the same penetration stage than A and B. D, transmission electron micrograph of a section through the germinal vesicle (GV) of a ovarian oocyte showing a penetrated spermatozoa inside the oocyte (es). E, Sperm (ES) inside of the ooplasm showing the chromatin (cr) in a cup-shape structure (cc) and the arms (arrows) and second metaphasic spindle (MI) perpendicular to surface. C, SEM view of sperm arms penetration. D, magnification of the figure $B$ showing the arms with chromatin migrating to the cup-shaped structure (cc). E, magnification of the sperm inside the ooplasm showing the chromatin in a cup-shaped structure (crsc) and chromatic in the arms (head arrow). Spines of the sperm arms (sp). C, D and $E$, transparented oocyte stained wit lacto-acetic orcein. (ps) perivitelline space. 
1991), is a microtubule polymerization center for forming the first cleavage spindle.

The participation of centrosome associated with the sperm centriole as a microtubule polymerization center has been confirmed in starfish (Yamada et al., 1990) and sea urchins (Schatten et al., 1986).

\section{Oocyte maturation and male pronucleus formation}

Of the oocytes obtained from females in the pre-molt period and fertilized in vitro, some were fertilized by two or more sperm and had two or more pronuclei. However, all the oocytes fertilized in vivo had only one male pronucleus. This coincides with the species Eriocheir sinensis (Lee and Yamazaki, 1989) but contrasts with the species Maia squinado and Carcinus maenas (Goudeau and Goudeau, 1985), which present a physiological polyspermy after fertilization. This difference in number of sperm penetrating the oocytes during fertilization could be related to the status of their meiotic maturation.

The oocytes which germinal vesicle is present tend to be polyspermic when performing in vitro fertilization, in contrast to the meiotic metaphase state oocytes, in which only one spermatozoon penetrates into the oocyte. In vivo the meiotic metaphase stage is reached between 22 to 26 hours after molting (Dupré, 1991; Martínez, 2008), which was demonstrated.

These oocytes are fertilized after spawning, which is likely to occur between 22 and 30 hours after the change of the female, since males exhibit mature mating behavior in the presence of molted females at 22 hours post-molt. A similar situation has been described for Paleomon serratus (Cledon, 1986). In this species germinal vesicle breakdown occurs within four hours before molting.

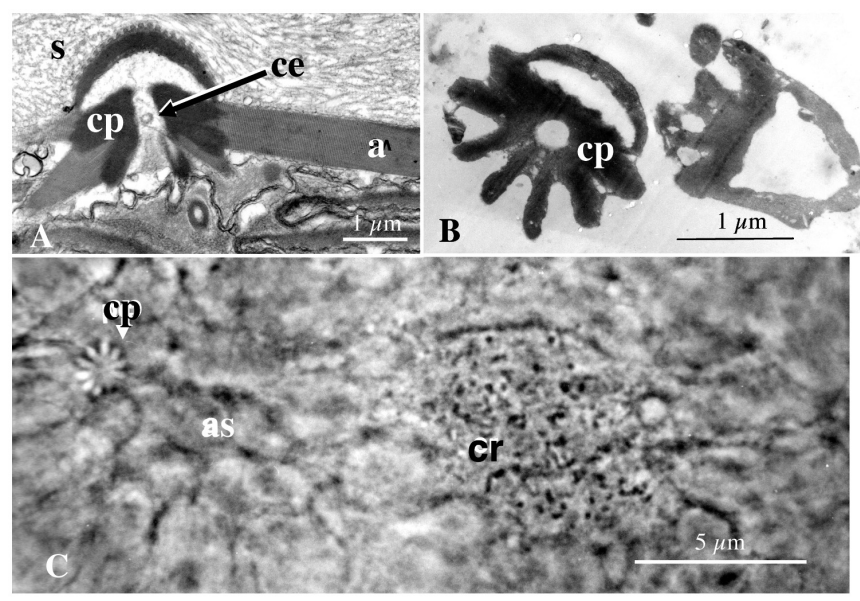

Figure 8: The connection piece of the spermatozoa. A, a transmission electron micrograph of a sagital section through vas deferens spermatozoa shown the arms (a) longitudinally cut, tangential section of the spike (s) and the connection piece (cp) as higher electron density at the base of the spike with a centriole in the central core (ce). B, connection pieces isolate from vas deferens spermatozoa. $C$, spindle of the first mitotic segmentation of the embryos showing the metaphasic chromosomes (cr), the connection piece (cp) close to the aster (as) of the spindle.
Sperm-egg interaction

The interaction between receptor molecules on the egg coat and the ligand on the spermatozoa has been reported in all the animals, which is fundamental to initiate sperm penetration. This interaction has been demonstrated in crustaceans in the shrimps Sicyonia ingentis (Pillai and Clark, 1990; Glas et al., 1996) and R. typus (Gómez, 2002; Gómez and Dupré, 2002; Dupré et al., 2010).

The results obtained from different studies (Gomez, 2002; Araya, 2005; Dupré et al., 2010) in the rock shrimp R. typus, have shown that the percentage of luminosity obtained with FITC-labeled lectins and permits the comparison of quantities of each of the monosaccharides recognized by the specific lectins at the different times of maturity. Dupré et al. (2010) showed the highest luminosity of the oocyte treated with LCA and GNL lectins, indicating a high concentration (compared to the other monosaccharides and controls) of the glucose and mannose respectively on the oocytes at all levels of oocyte maturation. This result agrees with previous studies carried out on oocyte envelopes in the shrimp Sicyonia ingentis (Pillai and Clark, 1990; Glas et al., 1996), the sea urchin Strongylocentrotus purpuratus (Correa and Carroll, 1997) and in cattle (Amari et al., 2001), in which oocyte envelopes had high mannose values.

The high luminosity of the envelopes treated with LCA lectin could be attributed to presence of mannose and glucose because this lectin recognizes both monosaccharide residues. However, the high luminosity is due mainly to the high concentration of mannose on the coat, as determined by GNL lectin, which is specific for mannose-1-3-mannose.

The major presence of Man ( $\alpha-1-3)$ Man, detected by GNL lectin, and N-Acetylglucosamine on the envelopes of different
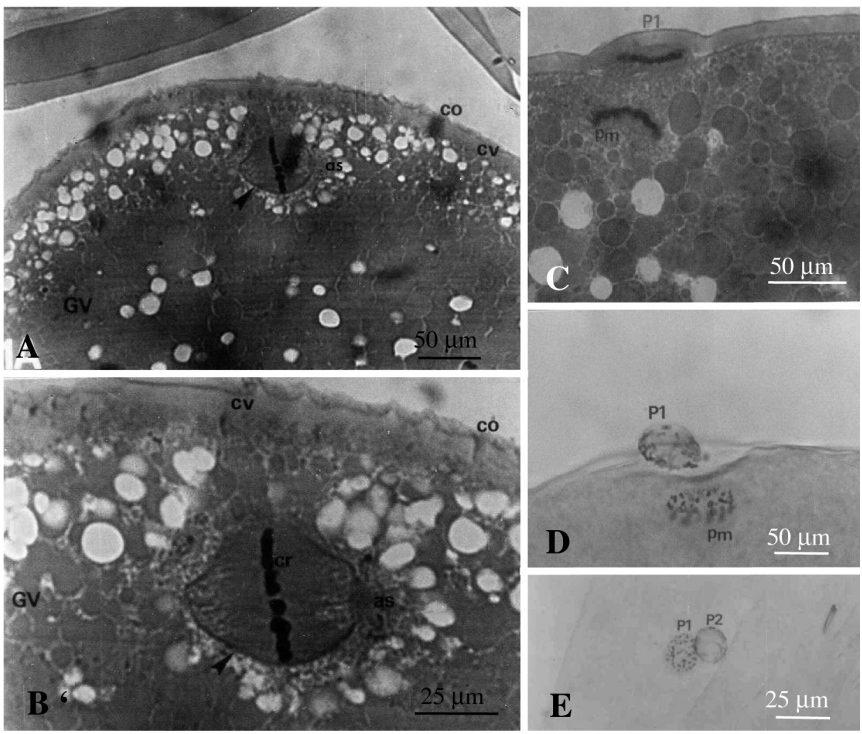

Figure 9: Meiotic re-initiation of the oocyte $20 \mathrm{~min}$ after the fertilization. A and B, first meiotic spindle. Note the lipid drops as clear vesicles. $C$, first meiotic telophase. D and E first (P1) and second (P2) polar body extruded after spermatozoon penetration. (pm) female pronucleus. (co) chorion. Viteline coat (cv). Yolk granule (GV). (Figs. A and B from Hierro, 1994). 
maturation stage oocytes of $R$, typus might be attributable to the eventual participation of these sugars in the primary or secondary gamete interaction as demonstrated in Phallusia mammillata, where N-Acetylglucosamine as well as N-acetylgalactosamine are implicated in the primary gamete interaction (Honegger, 1982; Litscher and Honegger, 1991) and they are the highest quantity on those oocyte envelopes (Litscher and Honegger, 1991). This was corroborated by Honegger (1982) through inhibition of fertilization using the WGA lectin, which adheres specifically to $\mathrm{N}$-acetyl-glucosamine where it blocks sperm adhesion sites. By analogy to the present data, we now suggest that $\mathrm{N}$-acetyl-glucosamine and mannose may be involved in the sperm-oocyte interaction in $R$. typus. This suggestion is supported by the strong inhibition of fertilization when spermatozoa were pre-treated with $\mathrm{N}$-acetylglucosamine (Dupré et al., 2010).

The results obtained suggest that the mechanism of the inhibition could be a lectin-like molecule on the tip of the spike of the spermatozoa (the distal end which interacts with the envelope of the oocyte as reported by Dupré and Barros, 1983, Barros et al., 1986; Dupré, 1991; Ríos, 1993; Palomino, 2000; Bustamante et al., 2001) capable of recognizing the oocyte sugars, which were specifically blocked during the incubation of the sperm with the corresponding monosaccharide.

A protein on the shrimp sperm analogous to the bindin of sea urchin sperm was postulated in previous studies (Barros et al., 1986; Dupré, 1991; Ríos, 1993; Bustamante et al., 2001), since a strong union was observed between the extreme distal portion of the sperm spike and the external envelope or chorion of mature oocytes in the shrimp. This union could not be broken by strong physical agitation of the oocyte with attached sperm. This phenomenon was again observed in the present study, and based on the results of inhibition of fertilization by the incubation of the sperm with mannose and glucose previous to insemination, it is suggested that the molecule responsible for recognition of carbohydrates on the oocyte envelope is a protein similar to bindin of sea urchin spermatozoa (Glabe et al., 1982).

According to Glabe et al., (1982), who proposed that bindin was a surface lectin, an explanation for the inhibition of the fertilization by the $\alpha$-N-Acetylglucosamine and $\alpha$-mannose and $\alpha$-D-glucose could be that free monosaccharides in the incubation medium adhere to the bindin-type protein located in the spike of the spermatozoa and block the active site to adhere to the oocyte ligand on the envelope.

The inhibition of fertilization does not determine if the interaction is associated with first or secondary sperm-oocyte interaction, nor if the most external or the inner-most zone of the coat binds to the spermatozoa, as shown in the shrimp Sycionia ingentis (Wikramanayake et al., 1994).

\section{RECOGNITION}

The present review, dedicated with great admiration to my great tutor and friend Dr. Claudio Barros, is a compilation of all the research studies about the reproduction of the rock shrimp, obtained by Dr. Claudio Barros's research group.

Financed partially by Fondecyt Grant No. 194-1121 and Fondef D05 I-10246.

\section{REFERENCES}

ANDERSON W, ELLIS R (1967) Cytodiferenciation of the crayfish spermatozoon: acrosome formation, transformation of mitochondrial and development of the microtubules Z Zellforsch 77: 80-94.

ARAYA A (2005) Ligandos espermáticos presentes en las cubiertas ovocitarias del camarón de roca Rhynchocinetes typus. Marine Biology thesis, Universidad Católica del Norte, Coquimbo, Chile. 52 pp.

BARROS C, DUPRÉ E, VIVEROS L (1986) Sperm-egg interactions in the shrimp Rynchocinetes typus. Gamete Res 14: 171-180.

BROWN A Jr, KLEVE MG, CLARK WH Jr (1976) Evidence for the presence of actin in Natantian sperm. Am. Zool. 16:180.

BROWN GG (1966) Ultrastructural studies of sperm morphology and spermegg interaction in the decapod Callinectes sapidus. J Ultrastruc Res 14: $425-440$

BUSTAMANTE E, PALOMINO J, AMOROSO A, MORENO R, BARROS C (2001) Purification and biochemical characterization of a trypsin-like enzyme present in the sperm of the rock shrimp Rhynchocinetes typus. Invert Reprod Develop 39: 175-181

CABRERA M (2003) Localización del pronucleo espermático del camarón de roca Rhynchocinetes typus (Milne-Edwards, 1837) durante la fecundación. Marine Biology thesis, Universidad Católica del Norte, Coquimbo, Chile. 49 pp.

CHEVAILLIER P, MAILLET C (1965) Structure fine et constitution cytochimique du spermatozoide de la langustine Nephrops norvegicus (Crustacea, Decapoda) J Microsc (Paris) 4: 679-700.

CLARK WH Jr, TALBOT P, NEAL RA, MOCK CR, SALSER R (1973) In vitro fertilization with non motile spermatozoa of the brown shrimp Penaeus aztecus. Mar Biol 22: 353-354

CLARK WH Jr, YUDIN AI, KLEVE MG (1981a) Primary binding in the gametes of the marine shrimp Sicyonia ingentis. J Cell Biol 91: 174a

CLARK WH Jr, KLEVE MG, YUDIN HI (1981b) An acrosome reaction in Natantia sperm. J Exp Zool 218: 279-291

CLEDON P (1986) Study on oocyte maturation and activation of the common prawn Palaemon serratus (Pennant): Relationship between oocyte maturation and the molt cycle cytological aspects. Gamete Res 13: 353 - 362.

DUPRÉ E (1991) Interacciones gaméticas en Rhynchocinetes typus (Crustacea, Decapoda, Natantia): Destino de las estructuras espermáticas y formación del pronucleo macho. Master of Biology Science, Universidad de Chile 53 pp

DUPRÉ E, ARAYA A, GOMEZ D, GALLARDO C (2010) Role of egg surface glycoconjugated in the fertilization of the rock shrimp Rhynchocinetes typus (Milne-Edwards, 1837) Lat Am J Aquat Res (in press).

DUPRÉ E, BARROS C (1983) Fine structure of the mature spermatozoon of Rhynchocinetes typus, Crustacea Decapoda. Gamete Res 7: 1-18

DUPRÉ E, BELLOLIO G (1994) Arquitectura del espermatozoide del camarón de roca Rhynchocinetes typus. Rev Invest Cientif Ser Cienc Mar UABCS, 5: 1-5

DUPRÉ E, SCHAAF G (1996) Influence of ion on the unfolding of the spermatozoa of the rock shrimp, Rhynchocinetes typus. J Exp Zool, 274: 358-364

DUPRÉ E, SCHATTEN G (1993) Microfilaments and DNA localization in lobster and cryfish spermatozoa. Biol Res 26: 529-537

GÓMEZ D (2002) Oligosacaridos presentes en las cubiertas ovocitarias del camarón de roca Rhynchocinetes typus, ¿receptores para la interacción espermatozoides-ovocito? Marine Biology thesis, Universidad Católica del Norte, Coquimbo, Chile.

GÓMEZ D, DUPRÉ E (2002) Monosacaridos terminales presentes en las cubiertas ovocitarias del camarón de roca Rhynchocinetes typus (Crustacea, Depadoda). Invest Mar, 30(2): 69-74

GOUDEAU H, GOUDEAU M, 1985 Fertilization in crab. IV. The fertilization potential consist of a sustained egg membrane hyperpolarization. Gamete Res 11: 1-17.

HIERRO R (1994) Cambios estructurales del espermatozoides de Rhynchocinetes typus durante el proceso de fecundación. Marine Biology thesis, Universidad Católica del Norte, Coquimbo, Chile 63 pp

HINSCH GW (1969) Microtubules in the sperm of spider crab Libinia emarginata. J Ultrastruct Res 29: 525-534

HINSCH GW (1971) Penetration of the oocyte envelope by spermatozoa in the spider crab. J Ultrastruct Res 35: 86-97.

KLAUS S, SCHUBART D, BRANDIS D 2009 Ultrastructure of the spermatozoa and spermatophores of the world freshwater crabs (Brachyura: Potamoidea: Gecarcinucidae, Potamonidae and Potamonautidea). J Morphol 270: 175-193. 
KLEVE MG, YUDIN AI, CLARK WH Jr (1980) Fine structure of the unistellate sperm of the shrimp Sycionia ingentis (Natantia). Tissue Cell 12: $29-45$.

KOHELER LD (1979) A unique case of cytodifferenciation: Spermiogenesis of the prawn Paleomonetes paludosus. J Ultrastruct Res 69: 109-120

LANGRETH SG (1965) Ultrastructural observations on the sperm of the crab Cancer borealis. J Cell Biol 27: 56A-57A.

LANGRETH S (1969) Spermiogenesis in the Cancer crabs. J Cell Biol 43: 575603

LEE TH, YAMAZAKI F (1989) Cytological observation on fertilization in the Chinesse freshwater crab, Eriocheir sinensis, by artificial insemination (in vitro) and incubation. Aquaculture 76: 347 - 360.

LOHRMANN K, RAINERI M 1995 Ultrastructure of the spermatozoa of the crab Cervimunida johni, (Galatheidae, Anomura, Crustacea). Inv Reprod Develop 28: 71-76.

LYNN JW, CLARK WH Jr (1980) Sperm morphology and early gamete interaction in the prawn Macrobrachium rosembergii. Am Zool 20: 875

LYNN JW, CLARK WH Jr (1983a) A morphological examination of spermegg interaction in the freshwater prawn, Macrobrachium rosembergii. Biol Bull 164: 446-458

LYNN JW, CLARK WH (1983b) The fine structure of the mature sperm of the freshwater prawn, Macrobrachium rosembergii. Biol Bull 164: 459-470.

MARTÍNEZ RM (2008) Funcionamiento de los apéndices involucrados en la transferencia de espermatóforos en Rhynchocinetes typus (Crustacea: Decapada: Rhynchocinetidae). Marine Biology thesis, Universidad Católica del Norte, Coquimbo, Chile. 46 pp.

MEDINA A, RODRÍGUEZ A 2005 Structural changes in sperm from the fiddler crab, Uca tangeri (Crustaceoa, Brachyura), during the acrosome reaction. Mol Reprod Develop 33 (2): 195-201.

MOSES MJ (1961) Spermiogenesis in the crayfish (Procambarus clarkii). I. Structural characterization of the mature sperm. J Biophys Biochem Cytol 9: 222-228

PALOMINO J (2000) Participación de moléculas de las cubiertas ovocitarias del camarón de roca Rhynchocinetes typus (Milne-Edwards, 1836) en la fecundación. Tesis para optar a título de Biólogo Marino Universidad Católica del Norte, Coquimbo 55 pp

PALOMINO J, MORENO R, BUSTAMENTE E, MESSEN L, DUPRÉ E, BARROS C (2002) Egg coats of the rock shrimp Rhynchocinetes typus: ultrastructural characterization and their function during the fertilization. J Exp Zool 293: 632-640.
PÉREZ C, CASTRO A, ROCO M, DUPRÉ E, BARROS C, SCHATTEN G (1990) Demonstration of F-actin and alfa tubulin in Rhynchocinetes typus spermatozoon. Mol Reprod Develop 28: 373-379.

PÉREZ C, ROCO M, CASTRO A, DUPRÉ E, SCHATTEN G, BARROS C (1991) Localization of filaments and tubulin-like protein in crustacean (Rhynchocinetes typus) spermatozoon. Mol Reprod Dev 28: 373 - 379.

PINTO M (2003) Formación del cigoto en el camarón de roca Rhynchocinetes typus (Milne-Edwards, 1837). Marine Biology thesis, Universidad Católica del Norte, Coquimbo, Chile. 47 pp.

POCHON-MASSON J 1965 Schéma du spermatozoide dévaginé de Homarus vulgaris (Decapode Macrure). C R Acad Sci 260: 5352-5354.

POCHON-MASSON J (1969) Infrastructure du spermatozoide de Paleomon elegans (De Man) (Crustacé Décapode) Arch Zool Exp Gen 110: 363-372

RÍOS M, BARROS C (1997) Trypsin-like enzymes during fertilization in the shrimp Rhynchocinetes typus. Mol Reprod Dev 46: 581-586

SANDIFER AP, LYNN WJ (1981) Artificial insemination of caridean shrimp. In: CLARK WH Jr, ADAM TS (eds) Advances in invertebrate reproduction. New York: Elsevier North Holland Inc. pp: 271-288.

SCHATTEN H, SCHATTEN G, MAZIA D, BALCZON R, SIMERLY C (1986) Behavior of centrosomes during fertilization and cell division in mouse oocytes and in sea urchin eggs. Proc Natl Acad Sci USA 83: 105-109

SIMEÓ C, KURTZ K, ROTLANT G, CHIVA M, RIBES E (2010) Sperm ultrastucture of the spider crab Maja brachydatyla (Decapoda: Brachyura). J Morphol 271: 407-417

TALBOT P, CHANMANON P (1980) Morphological feature of the acrosome reaction of lobster (Homarus) sperm and the roles of the reaction in generating forward movement. J Ultrastruct Res 70: 287-297.

TALBOT P, SUMMERS SR (1978) The structure of the sperm of Panulirus, the spiny lobster, with special regards to the acrosome J Ultrastruct Res 64: 341-351.

YAMADA H, KURAISHI R, AKIMURA RM, NAGANO H (1990) Injection of isolated centriolar complex to induce mitosis in starfish eggs. Mol Reprod Develop 26: 356-360.

YUDIN AI, CLARK WH Jr, KLEVE MG (1979) An acrosome reaction in natantian sperm. J Exp Zool 210: 569-574.

YUDIN AI, CLARK WH Jr, KLEVE MG (1980) Gamete binding in Sicyonia ingentis: Primary and Secondary. Am Zool 20: 875 
